\title{
Two novel missense mutations in the myelin protein zero gene causes Charcot-Marie-Tooth type 2 and Déjérine-Sottas syndrome
}

\author{
Geir J Braathen*1,2, Jette C Sand ${ }^{2}$ and Michael B Russell1,2
}

\begin{abstract}
Background: The Charcot-Marie-Tooth (CMT) phenotype caused by mutation in the myelin protein zero (MPZ) gene varies considerably, from early onset and severe forms to late onset and milder forms. The mechanism is not well understood. The myelin protein zero $\left(\mathrm{P}_{0}\right)$ mediates adhesion in the spiral wraps of the Schwann cell's myelin sheath. The crystalline structure of the extracellular domain of the myelin protein zero $\left(P_{0} e x\right)$ is known, while the transmembrane and intracellular structure is unknown.

Findings: One novel missense mutation caused a milder late onset CMT type 2, while the second missense mutation caused a severe early onset phenotype compatible with Déjérine-Sottas syndrome.

Conclusions: The phenotypic variation caused by different missense mutations in the MPZ gene is likely caused by different conformational changes of the MPZ protein which affects the functional tetramers. Severe changes of the MPZ protein cause dysfunctional tetramers and predominantly uncompacted myelin, i.e. the severe phenotypes congenital hypomyelinating neuropathy and Déjérine-Sottas syndrome, while milder changes cause the phenotypes CMT type 1 and 2.
\end{abstract}

\section{Background}

Charcot-Marie-Tooth (CMT) disease is characterized by distal muscle wasting and weakness, sensory loss with reduced tendon reflexes and foot deformities [1,2]. It is the most common inherited disorder of the peripheral nervous system with an estimated prevalence of 1 in 2,500 [3]. CMT is a heterogeneous disorder with respect to clinical features, neurophysiology, pathophysiology and genetics. The number of identified CMT genes is still expanding. So far the majority of the CMT genes encodes either neuronal or Schwann cell proteins [4]. However, the most frequent autosomal recessive form of CMT is caused by mutation in the glioside-induced differentiation-associated protein-1 (GDAP1) gene, which is located in the mitochondrial outer membrane and expressed in both neurons and Schwann cells [5].

The myelin protein zero $(M P Z)$ gene encodes a leader peptide of 29 amino acids which is cleaved from the

* Correspondence: g.j.braathen@medisin.uio.no

1 Faculty Division Akershus University Hospital, University of Oslo, 1474 Nordbyhagen, Oslo, Norway

Full list of author information is available at the end of the article remaining 219 amino acids before insertion in the myelin sheath [6]. The myelin protein zero $\left(\mathrm{P}_{0}\right)$ is post-translationally modified by additions of multiple sulphate, acyl and phosphate groups and an $\mathrm{N}$-linked oligosaccharide $[7,8] . \mathrm{P}_{0}$ has an extracellular, a transmembrane and a cytoplasmic domain. It is the most abundant protein in the myelin sheath of the peripheral nervous system [9]. The extracellular domain from myelin protein zero protein $\left(\mathrm{P}_{0} \mathrm{ex}\right)$ mediates homotypic adhesion, and it is essential for the formation of the compact myelin layer of Schwann cells $[10,11]$. It is included in the immunoglobulin supergene family, all members of which are involved in recognition and/or adhesion. X-ray crystallography suggests that $\mathrm{P}_{0}$ ex emanate from the membrane surface as tetramers that link to tetramers on the opposing membrane surface, to result in the formation of networks of molecules [12]. Knock-out mice without $\mathrm{P}_{0}$ expression develop a severe dysmyelinating neuropathy with predominantly uncompacted myelin [13].

The paper describes two novel missense mutations in the MPZ gene, and discusses possible mechanism in rela- 
tion to the phenotypic variability caused by different missense mutations in the $M P Z$ gene.

\section{Methods \\ Patients}

Norwegian patients with CMT disease were analyzed for mutations in the $M P Z$ gene. Affected were interviewed and had a neurological examination. The Neuropathy Impairment Score (NIS) and Charcot-Marie-Tooth disease neuropathy score (CMTNS) were used $[14,15]$. Nerve conduction velocities were recorded with surface electrodes, while needles were used for electromyography (EMG).

\section{Genetics}

DNA was extracted from leucocytes using QIAgen FlexiGene kit (Düsseldorf, Germany). The sequences were derived from the National Center for Biotechnology Information (NP_000521 and NM_000530, MPZ). The coding region of the $M P Z$ gene as well as exon and intron junctions were amplified using Eppendorf hotmaster taq polymerase. The sequencing was carried out using forward, reverse and internal primers, and BigDye Terminator kit version 1.1 Applied Biosystems (Life Technologies, Carslbad, CA, USA). Sequencing was performed using Applied Biosystems ABI3130x1 Genetic analyzer and aligned with the Sequencher programme (Gene Codes Corporation, Ann Arbor, MI). Numbering nomenclature used for the mutations includes the leader peptide of 29 amino acids.

\section{Statistical analysis}

SPSS for Windows version 14.0 was used for statistical analysis.

\section{Ethics}

The study was approved by the Regional Committees for Medical Research Ethics.

\section{Results}

Table 1 shows the demographics, clinical characteristics, phenotypes and novel MPZ missense mutations in three families. Additional file 1, table S2 shows the neurophysiology in the three families. The affected from family 1 was an immigrant from the Philippines, while family 2 and 3 originated from the same county and carried the same missense mutation. The affected in family 1 had early onset and severe symptoms compatible with Déjérine-Sottas syndrome (DSS), while affected in family 2 and 3 had late onset milder symptoms and axonal neuropathy compatible with CMT type 2 .

\section{Discussion}

Our main finding is the identification of two novel missense mutations in the MPZ gene. The phenotype/geno- type correlation is likely in family 1 , while three affected all carried the mutation in family 2 and 3 . Unfortunately we did not have DNA from the unaffected family members. However, the literature describes other missense mutations in the $M P Z$ gene that affects the same codons as our novel missense mutations [6,16-18]. Change of nucleotide 103 was not found in 100 unrelated controls, and change of nucleotide 368 was not found in 80 unrelated controls $[16,18]$. Thus, we suggest that the novel $M P Z$ missense mutations are disease causing rather than polymorphisms.

\section{Phenotype}

Missense mutations in the $M P Z$ gene account for about $2 \%$ of patients with CMT type 1 [18]. The phenotype varies considerably from early to late age at onset. Clinically missense mutations in the $M P Z$ gene can cause congenital hypomyelinating neuropathy $(\mathrm{CH})$, DSS, CMT type 1 , CMT type 2 and intermediate CMT [6,16-22]. The phenotypes $\mathrm{CH}$ and DSS are characterized by early onset and severe symptomatology, while the other phenotypes have a later age at onset and milder symptomatology. Our patients had phenotypes compatible with DSS and CMT type 2.

\section{Phenotype related to MPZ protein structure}

Our patient with DSS had a Gly123Asp amino acid substitution. Another patient with DSS had a Gly123Cys, while a patient with CMT type 1 had a Gly123Ser amino acid substitution $[6,18]$. Details about the patient with CMT type 1 are unfortunately not available. Ser has a structure that is much more similar to Gly than both Asp and Cys. Thus, the Gly123Ser amino acid change may cause less conformational changes of $\mathrm{P}_{0}$ than the Gly123Asp and Gly123Cys amino acid change. Similarly, missense mutations in the codon that include residue number 124 can cause CMT type 1 or CMT type 2 $[19,21,22]$. This is probably due to the characteristics of the specific amino acid substitution and the conformational changes of the MPZ protein. Our patients with CMT type 2 had Asp35Asn amino acid substitution. Asp and Asn has very similar structure and probably only causes minor conformational changes of $\mathrm{P}_{0}$, even though Asp is negatively charged and Asn is polar. Asp35Tyr causes intermediate CMT, CMT type 1 and CMT type 2 $[16,17]$. Tyr, a polar amino acid, has a hydroxyphenyl group that replace Asp charged side chain. The conformational change is likely to be small.

HeLa cells tranfected with two late onset and two early onset MPZ mutations showed that the two late onset mutations had normal transportation of the $\mathrm{P}_{0}$ to the cell membrane and moderately reduced MPZ-mediated intercellular adhesion, while the two early onset mutations had different patterns [23]. One early onset type was 
Table 1: Demographics, clinical characteristics, neurophysiology, phenotype and missense mutation for the three families.

\begin{tabular}{|c|c|c|c|c|}
\hline \multirow{2}{*}{$\begin{array}{l}\text { Family } \\
\text { Family member }\end{array}$} & \multirow[t]{2}{*}{1} & \multicolumn{2}{|c|}{2} & \multirow[t]{2}{*}{3} \\
\hline & & Father & Daughter & \\
\hline \multicolumn{5}{|l|}{ Demographic } \\
\hline Sex & q & $0^{x}$ & q & $0^{x}$ \\
\hline Age at onset & 2 & 70 & 29 & 56 \\
\hline Disease duration & 13 & 3 & 25 & 10 \\
\hline \multicolumn{5}{|l|}{ Clinical characteristics } \\
\hline \multicolumn{5}{|l|}{$\begin{array}{l}\text { Neurological } \\
\text { Impairment Score (NIS) }\end{array}$} \\
\hline cranial nerves & 0 & 0 & 0 & 0 \\
\hline Muscle weakness & 24 & 26 & 15 & 4 \\
\hline Reflexes & 16 & 16 & 2 & 4 \\
\hline Sensation & 24 & 6 & 6 & 2 \\
\hline Total NIS score & 64 & 48 & 23 & 10 \\
\hline \multicolumn{5}{|l|}{$\begin{array}{l}\text { Charcot-Marie-Tooth } \\
\text { disease neuropathy } \\
\text { score (CMTNS) }\end{array}$} \\
\hline Sensory symptoms & 3 & 0 & 3 & 3 \\
\hline \multicolumn{5}{|l|}{ Motor symptoms } \\
\hline Legs & 4 & 1 & 1 & 1 \\
\hline Arms & 1 & 0 & 0 & 0 \\
\hline Pin sensibility & 4 & 3 & 3 & 3 \\
\hline Vibration & 4 & 4 & 3 & - \\
\hline \multicolumn{5}{|l|}{ Strength } \\
\hline Legs & 1 & 3 & 1 & 4 \\
\hline Arms & 3 & 1 & 0 & 0 \\
\hline Ulnar/median CMAP & 2 & - & 0 & 1 \\
\hline Ulnar/median SNAP & 4 & - & 3 & 3 \\
\hline Total CMTNS score & 26 & 12 & 14 & 15 \\
\hline Ataxia & Marked & Slight & - & - \\
\hline Romberg & Positive & - & Positive & - \\
\hline Pes cavus & Present & - & Present & Present \\
\hline Kyphoscoliosis & Marked & Slight & 0 & 0 \\
\hline Phenotype & $\begin{array}{l}\text { Déjérine-Sottas } \\
\text { syndrome }\end{array}$ & $\begin{array}{c}\text { Charcot-Marie-Tooth } \\
\text { type } 2\end{array}$ & $\begin{array}{c}\text { Charcot-Marie-Tooth } \\
\text { type } 2\end{array}$ & $\begin{array}{c}\text { Charcot-Marie-Tooth } \\
\text { type } 2\end{array}$ \\
\hline Missense mutation & $368 \mathrm{G}>\mathrm{A}$ & $103 \mathrm{G}>\mathrm{A}$ & $103 \mathrm{G}>\mathrm{A}$ & $103 \mathrm{G}>\mathrm{A}$ \\
\hline Amino acid change & Gly123Asp & Asp35Asn & Asp35Asn & Asp35Asn \\
\hline
\end{tabular}


correctly glycosylated and trafficked to the plasma membrane, but intercellular adhesion was strongly affected, while the other early onset type caused by deletion in the gene showed that the transcripted $\mathrm{P}_{0}$ was retained within the cytoplasm with secondary reduced adhesion. The Ser63del causes a demyelinating neuropathy in transgenic mice, similar to the Ser63del causes a CMT type 1 in humans [24-26]. Interestingly, the $\mathrm{P}_{0}$ Ser63del is retained in the endoplasmic reticulum, and it fails to be incorporated into myelin [24,25]. These are very interesting mechanisms which are not directly related to the conformational change of the $\mathrm{P}_{0}$. The retained $\mathrm{P}_{0}$ might be the mechanism that causes congenital hypomyelinating neuropathy $(\mathrm{CH})$. The literature provides several examples on allelic heterogeneity, i.e. mutations in one gene can cause different phenotypes. An example is mutations in the CACNA1A gene, which causes familial hemiplegic migraine (FHM-1), episodic ataxia (EA-2) or spinocerebellar ataxia (SCA-6) $[27,28]$. FHM-1 is characterized by sensory and motor aura followed by headache. The FHM1 families show both intra- and interfamilial variability. Affected from some FHM-1 families experience severe hemiplegic attacks, cerebral oedema and life threatening coma due to minor head trauma. The more common Charcot-Marie-Tooth genes identified so far show both locus and allelic heterogeneity. The allelic heterogeneity in the $M P Z$ gene is characterized by different types of neuropathy, in contrast to different disorders caused by mutations in the CACNA1A gene. At present it is anticipated that four $\mathrm{P}_{0}$ proteins form a tetramer and link to a tetramer of the opposed membrane. To our knowledge expression of the $M P Z$ alleles is unknown. If one allele is expressed per cell, it will either be a wild type or changed $\mathrm{P}_{0}$. However, if both alleles are expressed equally, tetramer assembly would statistically be in the order 1:16, 4:16, 6:16, 4:16, 1:16 for the different combinations of wild type and changed $P_{0}$. Thus, only 1:256 (1:162) will be normal tetramers that can link together. A sural nerve biopsy of a patient with $\mathrm{CH}$ caused by a mutation in $\mathrm{P}_{0}$ presented a characteristic picture of non-myelinated and poorly myelinated axons with basal lamina onion bulbs and lack of myelin breakdown products [29]. The histology supports that both alleles, i.e. the wild type and mutated allele, are expressed in each Schwann cell. If only one allele was expressed per cell, one would expect to observe both normal and abnormal Schwann cell histology, i.e. normal and abnormal myelination along the axon. The assembly of different tetramers may also explain the intrafamilial variation of symptoms and age at onset $[16,24]$. Even a concordant monozygotic twin pair was described with different progression, classified as Roussy-Lévy variant of CMT1 and CMT1, respectively [30]. We cannot exclude the importance of environmen- tal factor with certainty. However we do not think the environment has a crucial role given proper nutrition and exclusion of other neuropathy inducing factors.

\section{Conclusions}

We suggest that the phenotypic variation caused by different missense mutation in the $M P Z$ gene is closely linked to the effects on the MPZ protein tetramers, which is crucial for axonal myelination.

\section{Additional material}

Additional file $\mathbf{1}$ Table S2. Neurophysiology in patients with Charcot-

Marie-Tooth disease caused by point mutations in the MPZ.

\section{Competing interests}

The authors declare that they have no competing interests.

\section{Authors' contributions}

GJB acquired the material, conceived the study, participated in the design of the study and drafted the manuscript. JCS carried out the molecular genetic studies and the sequence alignment. MBR conceived the study, participated in the design of the study and drafted the manuscript. All authors read and approved the final manuscript.

\section{Acknowledgements}

The study was financially supported by University of Oslo, Faculty Division Akershus University Hospital, Helse Øst, Sentralsykehuset i Akershus and Nansen Foundation.

\section{Author Details}

1Faculty Division Akershus University Hospital, University of Oslo, 1474 Nordbyhagen, Oslo, Norway and $2 \mathrm{Head}$ and Neck Research Group, Research Centre, Akershus University Hospital, 1478 Lørenskog, Oslo, Norway

Received: 25 September 2009 Accepted: 12 April 2010

Published: 12 April 2010

\section{References}

1. Charcot JM, Marie $P$ : Sur une form particulière d'atrophie musculaire progressive, souvant familiale, debutant par les pieds et les jambes, et atteignant plus tard les mains. Rev Méd Paris 1886, 6:97-138.

2. Tooth $\mathrm{HH}$ : The Peroneal Type of Progressive Muscular Atrophy. London: H. K. Lewis pub; 1886.

3. Skre H: Genetic and clinical aspects of Charcot-Marie-Tooth's disease. Clin Genet 1974, 6:98-118.

4. Shy ME, Garbern JY, Kamholz J: Hereditary motor and sensory neuropathies; a biological perspective. Lancet Neurol 2002, 1:110-118.

5. Niemann A, Ruegg M, La Padula V, Schenone A, Suter U: Gangliosideinduced differentiation-associated protein-1 is a regulator of the mitochondrial network:new implications for Charcot-Marie-Tooth disease. J Cell Biol 2005, 170:1067-1078.

6. Inherited Peripheral Neuropathies Mutation Database [http:// www.molgen.ua.ac.be/CMTMutations/1. (accessed 09/02/2010)

7. D'Urso D, Brophy PJ, Staugaitis SM, Gillespie CS, Frey AB, Stempak JG, Colman DR: Protein zero of peripheral nerve myelin:biosynthesis, membrane insertion, and evidence for homotypic interaction. Neuron 1990, 4:449-460

8. Eichberg J, lyer S: Phosphorylation of myelin protein:recent advances. Neurochem Res 1996, 21:527-535.

9. Lemke G: Unwrapping the genes of myelin. Neuron 1988, 1:535-543.

10. Lemke $G$, Axel R: Isolation and sequence of a cDNA encoding the major structural protein of peripheral myelin. Cell 1985, 40:501-508.

11. Filbin MT, Walsh FS, Trapp BD, Pizzey JA, Tennekoon Gl: Role of myelin P0 protein as a homophilic adhesion molecule. Nature 1990, 344:871-872. 
12. Shapiro L, Doyle JP, Hensley P, Colman DR, Hendrickson WA: Crystal structure of the extracellular domain from $\mathrm{P0}$, the major structural protein of peripheral nerve myelin. Neuron 1996, 17:435-449.

13. Xu W, Manichella D, Jiang H, Vallat JM, Lilien J, Baron P, Scarlato G, Kamholz J, Shy ME: Absence of PO leads to the dysregulation of myelin gene expression and myelin morphogenesis. J Neurosci Res 2000, 60:714-724.

14. Dyck PJ, Turner DW, Davies JL, O'Brien PC, Dyck PJ, Rask CA: Electronic case-report forms of symptoms and impairments of peripheral neuropathy. Can J Neurol Sci 2002, 29:258-266.

15. Shy ME, Blake J, Krajewski K, Fuerst DR, Laura M, Hahn AF, Li J, Lewis RA, Reilly M: Reliability and validity of the CMT neuropathy score as a measure of disability. Neurology 2005, 64:1209-1214.

16. Mastaglia FL, Nowak KJ, Stell R, Phillips BA, Edmondston JE, Dorosz SM Wilton SD, Hallmayer J, Kakulas BA, Laing NG: Novel mutation in the myelin protein zero gene in a family with intermediate hereditary motor and sensory neuropathy. J Neurol Neurosurg Psychiatry 1999, 67:174-179.

17. Hattori N, Yamamoto M, Yoshihara T, Koike H, Nakagawa M, Yoshikawa $H$ Ohnishi A, Hayasaka K, Onodera O, Baba M, Yasuda H, Saito T, Nakashima K, Kira J, Kaji R, Oka N, Sobue G, Study Group for Hereditary Neuropathy in Japan: Demyelinating and axonal features of Charcot-Marie-Tooth disease with mutations of myelin-related proteins (PMP22, MPZ and Cx32):a clinicopathological study of 205 Japanese patients. Brain 2003, 126:134-151.

18. Boerkoel CF, Takashima H, Garcia CA, Olney RK, Johnson J, Berry K, Russo P, Kennedy S, Teebi AS, Scavina M, Williams LL, Mancias P, Butler IJ, Krajewski K, Shy M, Lupski JR: Charcot-Marie-Tooth disease and related neuropathies:mutation distribution and genotype-phenotype correlation. Ann Neurol 2002, 51:190-201.

19. De Jonghe P, Timmerman V, Ceuterick C, Nelis E, De Vriendt E, Löfgren A, Vercruyssen A, Verellen C, Van Maldergem L, Martin JJ, Van Broeckhoven C: The Thr124Met mutation in the peripheral myelin protein zero MPZ gene is associated with a clinically distinct Charcot-Marie-Tooth phenotype. Brain 1999, 122:281-290.

20. Shy ME, Jáni A, Krajewski K, Grandis M, Lewis RA, Li J, Shy RR, Balsamo J, Lilien J, Garbern JY, Kamholz J: Phenotypic clustering in MPZ mutations. Brain 2004, 127:371-384

21. Schiavon F, Rampazzo A, Merlini L, Angelini C, Mostacciuolo ML: Mutations of the same sequence of the myelin PO gene causing two different phenotypes. Hum Mutat 1998:S217-219.

22. Chapon F, Latour P, Diraison P, Schaeffer S, Vandenberghe A: Axonal phenotype of Charcot-Marie-Tooth disease associated with a mutation in the myelin protein zero gene. J Neurol Neurosurg Psychiatry 1999, 66:779-782.

23. Grandis M, Vigo T, Passalacqua M, Jain M, Scazzola S, La Padula V, Brucal M, Benvenuto F, Nobbio L, Cadoni A, Mancardi GL, Kamholz J, Shy ME, Schenone A: Different cellular and molecular mechanisms for early and late-onset myelin protein zero mutations. Hum Mol Genet 2008:1877-1889.

24. Wrabetz L, D'Antonio M, Pennuto M, Dati G, Tinelli E, Fratta P, Previtali S, Imperiale D, Zielasek J, Toyka K, Avila RL, Kirschner DA, Messing A, Feltri ML, Quattrini A: Different intracellular pathomechanisms produce diverse Myelin Protein Zero neuropathies in transgenic mice. J Neurosci 2006, 26:2358-2368

25. Pennuto M, Tinelli E, Malaguti M, Del Carro U, D'Antonio M, Ron D, Quattrini A, Feltri ML, Wrabetz L: Ablation of the UPR-mediator CHOP restores motor function and reduces demyelination in Charcot-MarieTooth 1B mice. Neuron 2008, 57:393-405.

26. Kulkens $T$, Bolhuis PA, Wolterman RA, Kemp S, te Nijenhuis S, Valentijn $L J$ Hensels GW, Jennekens FG, de Visser M, Hoogendijk JE, Baas F: Deletion of the serine 34 codon from the major peripheral myelin protein $\mathrm{PO}$ gene in Charcot-Marie-Tooth disease type 1B. Nat Genet 1993, 5:35-39.

27. Ophoff RA, Terwindt GM, Vergouwe MN, van Eijk R, Oefner PJ, Hoffman SM, Lamerdin JE, Mohrenweiser HW, Bulman DE, Ferrari M, Haan J, Lindhout D, van Ommen GJ, Hofker MH, Ferrari MD, Frants RR: Familial hemiplegic migraine and episodic ataxia type- 2 are caused by mutations in the Ca2+ channel gene CACNL1A4. Cell 1996, 87:543-552.

28. Zhuchenko O, Bailey J, Bonnen P, Ashizawa T, Stockton DW, Amos C, Dobyns WB, Subramony SH, Zoghbi HY, Lee CC: Autosomal dominant cerebellar ataxia (SCA6) associated with small polyglutamine expansions in the alpha 1A-voltage-dependent calcium channel. Nat Genet 1997, 15:62-69.

29. Kochanski A, Drac H, Kabziñska D, Ryniewicz B, Rowiñska-Marciñska K, Nowakowski A, Hausmanowa-Petrusewicz I: A novel MPZ gene mutation in congenital neuropathy with hypomyelination. Neurology 2004, 62:2122-2123

30. Marques W Jr, Hanna MG, Marques SR, Sweeney MG, Thomas PK, Wood NW: Phenotypic variation of a new PO mutation in genetically identical twins. J Neurol 1999, 246:596-599.

doi: 10.1186/1756-0500-3-99

Cite this article as: Braathen et al., Two novel missense mutations in the myelin protein zero gene causes Charcot-Marie-Tooth type 2 and DéjérineSottas syndrome BMC Research Notes 2010, 3:99

\section{Submit your next manuscript to BioMed Central and take full advantage of:}

- Convenient online submission

- Thorough peer review

- No space constraints or color figure charges

- Immediate publication on acceptance

- Inclusion in PubMed, CAS, Scopus and Google Scholar

- Research which is freely available for redistribution

Submit your manuscript at www.biomedcentral.com/submit
C Biomed Central 